\title{
Targeting the Fc $\mu$-receptor in chronic lymphocytic leukemia with a novel IgM-derived antibody-drug conjugate
}

\author{
Martin Skarzynski ${ }^{*}$, Bérengère Vire ${ }^{1}$, Joshua D Thomas ${ }^{2}$, Christopher G Nelson², Alexandre David ${ }^{3}$, Georg Aue $^{1}$, \\ Terrence R Burke ${ }^{2}$, Christoph Rader ${ }^{4,5}$, Adrian Wiestner ${ }^{1}$
}

From Society for Immunotherapy of Cancer 28th Annual Meeting

National Harbor, MD, USA. 8-10 November 2013

Fc-receptors (FcR) are widely expressed on cells of the immune system. $\mathrm{F}_{\mathrm{c}} \mu \mathrm{R}$ is a transmembrane protein with an extracellular Ig-like domain homologous to the FcR for both IgA and IgM $(\mathrm{Fc} \alpha / \mu \mathrm{R})$ and the polymeric Ig receptor (pIgR). Fc $\mu \mathrm{R}$ is expressed on CD19+B cells, CD4+/CD8+ $\mathrm{T}$ cells, and CD56+/CD3- NK cells. In addition, several groups have reported that $\mathrm{Fc} \mu \mathrm{R}$ is overexpressed in chronic lymphocytic leukemia (CLL) cells. Using immunofluorescence staining, we found that $\mathrm{F} c \mu \mathrm{R}$ can rapidly uptake IgM, internalize it in specific vesicles and transport it through the endocytic pathway to the lysosomal compartment. Interestingly, aggregation of $\mathrm{Fc} \mu \mathrm{R}$ with $\operatorname{IgM}$ leads to rapid internalization of IgM $(>80 \%$ internalized within 5 minutes) whereas $\mathrm{mAb}$ bound $\mathrm{Fc} \mu \mathrm{R}$ is not internalized. Overexpression on CLL cells and rapid internalization of $\mathrm{F} c \mu \mathrm{R}$ represents a potential means of selectively delivering a cytotoxic agent into malignant cells. To this end, we engineered a protein scaffold derived from the $\mathrm{CH} 2-\mathrm{CH} 3-\mathrm{CH} 4 \mathrm{IgM}$ constant regions with a C-terminal selenocysteine that allows covalent conjugation of drugs or toxins to the protein scaffold. We verified that the scaffold also binds $F c \mu R$, is rapidly internalized and has a serum circulatory half-life comparable to IgM ( 18hrs) in NOD/SCID/IL-2R rnull (NSG) mice. We then demonstrated that the scaffold, when conjugated to a cytotoxic small molecule, kills malignant B cells, but not normal $\mathrm{T}$ cells, from CLL patients in vitro and in NSG mice. These findings indicate that the rapid internalization of IgM-Fc $\mu \mathrm{R}$ complexes can be exploited for therapeutic

${ }^{1}$ Hematology Branch, National Heart, Lung, and Blood Institute, Bethesda, MD, USA

Full list of author information is available at the end of the article purposes. Taken together, IgM-derived protein scaffold antibody-drug conjugates appear as promising treatment modalities for CLL and possibly other malignancies.

\section{Authors' details}

'Hematology Branch, National Heart, Lung, and Blood Institute, Bethesda, MD, USA. ${ }^{2}$ Chemical Biology Laboratory, Molecular Discovery Program, Frederick National Laboratory for Cancer Research, Center for Cancer Research, National Cancer Institute, Frederick, MD, USA. ${ }^{3}$ Laboratory of Viral Diseases, National Institute of Allergy and Infectious Diseases, Bethesda, MD, USA. ${ }^{4}$ Experimental Transplantation and Immunology Branch, Center for Cancer Research, National Cancer Institute, Bethesda, MD, USA. ${ }^{5}$ Department of Cancer Biology and Department of Molecular Therapeutics, The Scripps Research Institute, Scripps Florida, Jupiter, FL, USA.

Published: 7 November 2013

\section{doi:10.1186/2051-1426-1-S1-P136}

Cite this article as: Skarzynski et al:: Targeting the Fcu-receptor in chronic lymphocytic leukemia with a novel IgM-derived antibody-drug conjugate. Journal for ImmunoTherapy of Cancer 2013 1(Suppl 1):P136.

Submit your next manuscript to BioMed Central and take full advantage of:

- Convenient online submission

- Thorough peer review

- No space constraints or color figure charges

- Immediate publication on acceptance

- Inclusion in PubMed, CAS, Scopus and Google Scholar

- Research which is freely available for redistribution

\section{() Biomed Central}

